2020-01-20

\title{
Clam feeding plasticity reduces herbivore vulnerability to ocean warming and acidification
}

\section{Van Colen, C}

http://hdl.handle.net/10026.1/15342

\subsection{8/s41558-019-0679-2}

Nature Climate Change

Springer Science and Business Media LLC

All content in PEARL is protected by copyright law. Author manuscripts are made available in accordance with publisher policies. Please cite only the published version using the details provided on the item record or document. In the absence of an open licence (e.g. Creative Commons), permissions for further reuse of content should be sought from the publisher or author. 
This is the unformatted version of the accepted manuscript. The published formatted version of this article is available on: https://www.nature.com/articles/s41558-019-0679-2

\section{Clam feeding plasticity reduces herbivore vulnerability to ocean warming and acidification}

Carl Van Colen ${ }^{\mathrm{a}^{*}}$, Ee Zin Ong ${ }^{\mathrm{a}, \mathrm{b}}$, Mark Briffa $^{\mathrm{b}}$, David S. Wethey ${ }^{\mathrm{c}}$, Emmanuel Abatih ${ }^{\mathrm{d}}$, Tom Moens ${ }^{\mathrm{a}}$, Sarah A. Woodin ${ }^{\mathrm{c}}$

${ }^{a}$ Ghent University, Biology Department, Marine Biology Research Group, Krijgslaan 281 - S8, B 9000 Ghent, Belgium

${ }^{\mathrm{b}}$ School of Biological and Marine Sciences, University of Plymouth, Plymouth PL4 8AA, UK

${ }^{c}$ Department of Biological Sciences, University of South Carolina, Columbia, SC 29208, USA

${ }^{\mathrm{d}}$ Ghent University, Department of Applied Mathematics, Computer Science and Statistics, Krijgslaan 281 - S9, B 9000 Ghent, Belgium

* corresponding author: carl.vancolen@ugent.be

Ocean warming and acidification affect species populations, but how interactions within communities are affected and how this translates into ecosystem functioning and resilience remains poorly understood. Here we demonstrate that experimental ocean warming and acidification significantly alters the interaction network among porewater nutrients, primary producers, herbivores and burrowing invertebrates in a seafloor sediment community, and is linked to behavioral plasticity in the clam Scrobicularia plana. Warming and acidification induced a shift in the clam's feeding mode from predominantly suspension feeding under ambient conditions to deposit feeding with cascading effects on nutrient supply to primary producers. Surface-dwelling invertebrates were more tolerant to warming and acidification in the presence of $S$. plana, most likely due to the stimulatory effect of the clam on their microalgal food resources. This study demonstrates that predictions of population resilience to climate change require consideration of non-lethal effects such as behavioral changes of key species. 
Modifications of behavior are often among the first responses of animals to changing environmental conditions ${ }^{1}$. Behavioral activities such as predator avoidance, competition with other individuals, and obtaining food affect population health, community interactions and engineering effects on the abiotic environment that define ecosystem functioning and dynamics. Consequently, insights into behavioral responses of species, and the feedback processes with other components of their ecosystem, may be paramount to better understand the mechanisms that underpin (lack of) resilience to, and the concomitant loss of ecosystem goods and services as a consequence of multiple stressors ${ }^{2-4}$, such as those associated with climate change. While climate change effects are being studied at multiple levels of biological organization, insights into how animal behavior shapes the ecological effects of climate change nevertheless remain underrepresented ${ }^{5}$.

In marine ecosystems, warming and acidification resulting from oceanic $\mathrm{CO}_{2}$ uptake are considered evil siblings ${ }^{6}$, acting in concert with complex, often synergistic, effects ${ }^{7}$. Warming and acidification occur particularly rapidly in shallow-water habitats, possibly exacerbated by nearby land warming and fast organic matter mineralization in highly productive coastal seas ${ }^{8,9}$. Soft-sediments encompass the majority of seafloor habitats and are densely inhabited by burrowing fauna whose activities contribute importantly to organic matter mineralization and nutrient cycling that support marine food webs ${ }^{10,11}$. The largely sedentary life style of most soft-sediment fauna necessitates evolutionary adaptation and/or physiological and behavioral plasticity to cope with warming and acidification. Behavioral change can, however, instigate a suite of cascading effects that are difficult to interpret due to the many interconnected ecosystem components, each with different tolerances to warming and acidification ${ }^{12,13}$. For example, the active redistribution of particles, water and solutes in seafloor sediments related to feeding activity, excretion and burrow ventilation of macrofauna, such as by burrowing clams and bristle worms, are known to modify resource availability to other populations ${ }^{14}$.

We conducted two separate experiments to test how behavior of a key species, the tellinid clam Scrobicularia plana, shape the response of communities to climate change. Scrobicularia plana is one of the most common large burrowing bivalves along the North Eastern Atlantic, Mediterranean and Baltic sea coastlines, where it is an important prey species for wading birds ${ }^{15}$, and affects other 
sediment fauna and sediment biogeochemistry ${ }^{16}$. It depends on its inhalant siphon to feed on organic matter in the sediment surface (i.e. deposit feeding), or suspended in the water column (i.e. suspension feeding ${ }^{17}$. We incubated clams and soft-sediment communities for 4 weeks under experimental warming and acidification $\left(3^{\circ} \mathrm{C}\right.$ increase and $\sim 0.35 \mathrm{pH}_{\mathrm{T}}$ unit decline from ambient conditions; see Methods). First, we analyzed porewater hydraulic signatures that are associated with different behaviors of S. plana to study how the single and combined effects of experimental warming and acidification influence feeding behavior. Second, we collected soft-sediment communities and analyzed how the presence of $S$. plana mediated combined warming and acidification effects on ecosystem interactions and population resilience via direct and indirect pathways.

\section{Feeding behavior}

Acidification significantly decreased the frequency of suspension feeding events $\left(F_{1,12}=6.27, p=\right.$ 0.028), independently of warming (warming $\times$ acidification interaction: $F_{1,12}=0.29, p=0.603$; effect of warming: $F_{1,12}=1.64, p=0.224$ )(Fig. 1a). In contrast, warming significantly increased the frequency of deposit feeding events $\left(\mathrm{F}_{1,12}=9.34, \mathrm{p}=0.010\right)$ independently of acidification (warming $\times$ acidification interaction: $F_{1,12}=0.43, p=0.523$; effect of acidification: $\left.F_{1,12}=0.002, p=0.902\right)($ Fig. 1a). Similarly, there were no interactive warming and acidification effects on the total duration spent on suspension or deposit feeding (suspension feeding: $F_{1,12}=0.78, p=0.396$; deposit feeding: $F_{1,12}=$ $0.24, p=0.636)$, but acidification significantly reduced the total suspension feeding time $\left(F_{1,12}=9.73\right.$, $\mathrm{p}=0.009)$ while warming significantly increased the total deposit feeding time $\left(\mathrm{F}_{1,12}=5.32, \mathrm{p}=\right.$ 0.040)(Fig. 1b). Consequently, S. plana fed longer and almost exclusively via deposit feeding under combined warming and acidification, while suspension feeding was the predominant feeding mode under ambient temperature and $\mathrm{pH}$, and prior to manipulation (Supplementary Fig. 1). This shift in feeding behavior is associated with changes in porewater hydraulics resulting from the release of water below the sediment surface through the exhalant siphon during feeding. Suspension feeding generates longer periods of strong porewater pressurizations with a gradual pressure release (Fig. 1c). In contrast, pressurizations associated with deposit feeding are continuously interrupted by pressure 
release from small 'coughs' that remove plugs of sediment from the inhalant siphon, preventing pressure build up and limiting feeding duration (Fig. 1d).

\section{Benthic microalgae and porewater nutrients}

Combined warming and acidification decreased benthic microalgal biomass relative to ambient conditions $\left(\mathrm{F}_{1,7.73}=6.91, \mathrm{p}=0.031\right)$, independently of S. plana presence (Fig. 2a)(Supplementary Table 1). The presence of $S$. plana reduced the concentration of porewater $\mathrm{NO}_{2}^{-}$, but only under ambient temperature and $\mathrm{pH}\left(\right.$ climate condition $\times$ S. plana interaction: $\left.\mathrm{F}_{1,7.70}=6.32, \mathrm{p}=0.037\right)(\mathrm{Fig}$. 2b)(Supplementary Table 1). The porewater concentration of $\mathrm{NO}_{3}{ }^{-}$was not affected by combined warming and acidification but the presence of $S$. plana decreased the $\mathrm{NO}_{3}{ }^{-}$concentration $\left(\mathrm{F}_{1,8.67}=\right.$ 4.63, $\mathrm{p}=0.061$ ), with the lowest concentrations found under ambient temperature and $\mathrm{pH}$ when $S$. plana was present (Fig. 2c)(Supplementary Table 1). Porewater $\mathrm{Si}, \mathrm{NH}_{4}{ }^{+}$and $\mathrm{PO}_{4}{ }^{3-}$ concentrations and the proportion of living : dead benthic microalgae were not significantly affected by $S$. plana presence, nor by combined warming and acidification or by their interaction (Supplementary Table 1). However, $\mathrm{Si}$ and $\mathrm{PO}_{4}{ }^{3-}$ concentrations were lowest, and the proportion of living : dead benthic microalgae was highest, under combined warming and acidification when S. plana was present (Fig. 2d-f), suggesting enhanced growth of benthic microalgae and therefore increased utilization of $\mathrm{Si}$ and $\mathrm{PO}_{4}{ }^{3-}$.

\section{Sediment fauna}

The presence of $S$. plana strongly enhanced the density of the subsurface deposit feeding red thread worm Heteromastus filiformis $\left(\chi^{2}{ }_{1}=17.68, \mathrm{p}<0.001\right)$ and moderately decreased the density of the omnivorous ragworm Hediste diversicolor $\left(\chi^{2}{ }_{1}=8.19, p=0.004\right)$, independently of combined warming and acidification (Fig. 3a, c)(Supplementary Table 2). Combined warming and acidification strongly reduced the density of the herbivorous snail Peringia ulvae, particularly in the absence of $S$. plana $\left(\right.$ climate condition $\times$ S. plana interaction: $\left.\chi^{2}{ }_{1}=94.84, \mathrm{p}<0.001\right)($ Fig. $3 b)($ Supplementary Table

2). Similarly, the total density of nematodes in the upper first $\mathrm{cm}$ of the sediment decreased under combined warming and acidification only in the absence of S. plana (climate condition $\times$ S. plana interaction: $\left.\chi^{2}{ }_{1}=32.55, \mathrm{p}<0.001\right)($ Fig. 3d)(Supplementary Table 2). 


\section{Ecosystem interaction network}

The interaction network structure drastically changed in response to combined ocean warming and acidification (Fig. 4)(Supplementary Table 3). Under ambient temperature and pH (Fig. 4a), the proportion of living : dead benthic microalgae was negatively influenced by $H$. diversicolor. However, the top-down control by $H$. diversicolor was weakened by the negative effect of S. plana on $H$. diversicolor. In contrast, $S$. plana had a strong direct positive effect on $H$. filiformis, which was strengthened indirectly by reducing the negative effect of $H$. diversicolor on $H$. filiformis.

Furthermore, S. plana strongly reduced porewater $\mathrm{NO}_{3}{ }^{-}$concentrations directly and indirectly via its effects on $H$. filiformis. A significant positive link between porewater $\mathrm{NO}_{3}{ }^{-}$and microalgae demonstrated that depleted $\mathrm{NO}_{3}{ }^{-}$concentrations reduced the freshness of organic matter derived from primary production by benthic microalgae.

Combined warming and acidification removed most of the interactions found under ambient temperature and $\mathrm{pH}$ (Fig. 4b). Only the direct positive effect of S. plana on H. filiformis was maintained, while the direct negative effect of $H$. diversicolor on the proportion of living : dead microalgae was non-significant $(\mathrm{p}=0.100)$ but was still required for model stability (see Methods). Additionally, a direct positive link between S. plana and microalgae was apparent; when combined with the positive effect of S. plana on P. ulvae and P. ulvae on microalgae, this link highlights the strong positive total effect of S. plana on benthic microalgal food quality under combined warming and acidification.

\section{Discussion}

Carbonate-rich marine sediments have a high buffering capacity for porewater $\mathrm{pH}$ decreases ${ }^{18}$, supporting the elevated $\mathrm{pH}\left(\sim 0.20 \mathrm{pH}_{\mathrm{T}}\right)$ in the surface sediment as compared to the overlying water column under acidified conditions (Extended Data Fig. 1). Shifting to deposit feeding in the surface sediment and reducing the intake of low $\mathrm{pH}$ water during suspension feeding in the water column therefore likely reduces the physiological disruptions associated with hypercapnia and acid-base regulation that can affect bioenergetics and depress growth ${ }^{19}$. This behavioral plasticity resulted in a less connected soft-sediment ecosystem interaction network. In particular, the interactions in which $S$. 
plana is involved change or disappear, except for the stimulatory effect on the subsurface deposit feeder $H$. filiformis that might benefit from enhanced oxygen and microbial food at depth related to $S$. plana irrigation ${ }^{17,20}$. Pressurizations associated with S. plana feeding disturb burrows ${ }^{17}$ and can therefore explain the clam interference effect on $H$. diversicolor; a burrowing species that construct open-ended burrow galleries that are ventilated for respiration purposes ${ }^{21}$. The loss of strong bioirrigators, such as $H$. diversicolor ${ }^{21}$, reduce sediment oxygenation and nitrification, especially when diffusive oxygen uptake from the water column is limited ${ }^{22}$. In contrast, increased feeding under combined warming and acidification stimulate bioadvective oxygenation and nutrient supply below the sediment surface ${ }^{14,23}$, facilitating aerobic $\mathrm{NO}_{3}{ }^{-}$generation through nitrification needed for biofilm development at the sediment surface after consumption of microalgae and disruption of the sediment surface during deposit feeding. Indeed, the structural equation model suggests $S$. plana-mediated facilitation of herbivore food quality (measured as the proportion of living : dead benthic microalgae) under combined warming and acidification, although gardening effects on food quantity (measured as microalgal biomass) might be masked by the elevated metabolism and grazing of the sediment community at higher temperatures ${ }^{24}$.

The grazing snail $P$. ulvae experienced high mortality from combined warming and acidification, corroborating meta-analysis that calcifying invertebrates are most vulnerable to acidification ${ }^{25}$. Similarly, surface-dwelling nematodes that rely on microalgae as a basal resource ${ }^{26}$ only suffered from combined warming and acidification when S. plana was absent. Ocean acidification is expected to reduce nitrification, and hence $\mathrm{NO}_{3}{ }^{-}$availability to primary producers ${ }^{27,28}$. Therefore, via their behavioral responses, $S$. plana can buffer climate change effects on soft-sediment seafloor communities, due to their stimulatory effects on food resources that may enhance tolerance to environmental changes such as reductions in seawater $\mathrm{pH}^{29,30}$. Consequently, population vulnerabilities to climate change will depend on the phenotypic plasticity of the populations, and on their functional role that underpins the complex interplay between organisms and their changing physical, chemical and biological habitat that defines ecosystem functioning. The loss of functionally important seafloor organisms, such as large burrowing bivalves, will thus undermine resilience of 
coastal seafloor sedimentary habitats that are at the frontline of rapid biogeochemical changes ${ }^{31}$. In general, this study highlights that mechanistic insights into non-lethal climate change effects are urgently needed to improve understanding of ocean warming and acidification in future oceans.

1. Tuomainen, U. \& Candolin, U. Behavioural responses to human-induced environmental change. Biol. Rev. 86, 640-657 (2011).

2. Zarnetske, P. L., Skelly, D. K. \& Urban, M. C. Biotic multipliers of climate change. Science $336,1516-1518$ (2012).

3. Dupont, S. \& Pörtner, H. Get ready for ocean acidification. Nature 489, 429 (2013).

4. Gilman, S. E., Urban, M. C., Tewksbury, J., Gilchrist, G. W. \& Holt, R. D. A framework for community interactions under climate change. Trends Ecol. Evol. 25, 325-331 (2010).

5. Nagelkerken, I. \& Munday, P. L. Animal behaviour shapes the ecological effects of ocean acidification and warming: Moving from individual to community-level responses. Glob. Change Biol. 22, 974-989 (2016).

6. Doney, S. C., Fabry, V. J., Feely, R. A. \& Kleypas, J. A. Ocean acidification: The other $\mathrm{CO}_{2}$ problem. Ann. Rev. Mar. Sci. 1, 169-192 (2009).

7. Harvey, B. P., Gwynn-Jones, D. \& Moore, P. J. Meta-analysis reveals complex marine biological responses to the interactive effects of ocean acidification and warming. Ecol. Evol. 3, 1016-1030 (2013).

8. Belkin, I. M. Rapid warming of large marine ecosystems. Prog. Oceanogr. 81, 207-213 (2009).

9. Provoost, P., van Heuven, S., Soetaert, K., Laane, R. W. P. M. \& Middelburg, J. J. Seasonal and long-term changes in pH in the Dutch coastal zone. Biogeosciences 7, 3869-3878 (2010).

10. Middelburg, J. J., Soetaert, K. \& Herman, P. M. J. Empirical relationships for use in global diagenetic models. Deep. Res. Part I 44, 327-344 (1997).

11. Snelgrove, P. V. R. et al. Global carbon cycling on a heterogeneous seafloor. Trends Ecol. Evol. 33, 96-105 (2018). 
12. Schade, $\mathrm{H}$. et al. Simulated leakage of high $\mathrm{pCO}_{2}$ water negatively impacts bivalve dominated infaunal communities from the Western Baltic Sea. Sci. Rep. 6, (2016).

13. Alsterberg, C., Eklöf, J. S., Gamfeldt, L., Havenhand, J. N. \& Sundbäck, K. Consumers mediate the effects of experimental ocean acidification and warming on primary producers. Proc. Natl. Acad. Sci. U. S. A. 110, 8603-8608 (2013).

14. Chennu, A. et al. Effects of bioadvection by Arenicola marina on microphytobenthos in permeable sediments. PLoS One 10, e0134236 (2015).

15. Wanink, J. H. \& Zwarts, L. Rate-maximizing optimality models predict when oystercatchers exploit a cohort of the bivalve Scrobicularia plana over a 7-year time span. J. Anim. Ecol. 70, $150-158$ (2001).

16. Clare, D. S., Spencer, M., Robinson, L. A. \& Frid, C. L. J. Species densities, biological interactions and benthic ecosystem functioning: An in situ experiment. Mar. Ecol. Prog. Ser. 547, 149-161 (2016).

17. Hughes, R. N. A study of feeding in Scrobicularia plana. J. Mar. Biol. Assoc. United Kingdom 49, 805-823 (1969).

18. Blackford, J. et al. Detection and impacts of leakage from sub-seafloor deep geological Carbon Dioxide Storage. Nat. Clim. Chang. 4, 1011-1016 (2014).

19. Michaelidis, B., Ouzounis, C., Paleras, A. \& Portner, H. O. Effects of long-term moderate hypercapnia on acid-base balance and growth rate in marine mussels Mytilus galloprovincialis. Mar. Ecol. Prog. Ser. 293, 109-118 (2005).

20. Volkenborn, N. \& Reise, K. Lugworm exclusion experiment: Responses by deposit feeding worms to biogenic habitat transformations. J. Exp. Mar. Bio. Ecol. 330, 169-179 (2006).

21. Nielsen, O. I., Gribsholt, B., Kristensen, E. \& Revsbech, N. P. Microscale distribution of oxygen and nitrate in sediment inhabited by Nereis diversicolor: spatial patterns and estimated reaction rates. Aquat. Microb. Ecol. 34, 23-32 (2004).

22. Stief, P. Stimulation of microbial nitrogen cycling in aquatic ecosystems by benthic macrofauna: Mechanisms and environmental implications. Biogeosciences 10, 7829-7846 (2013). 
23. Volkenborn, N. et al. Intermittent bioirrigation and oxygen dynamics in permeable sediments: An experimental and modeling study of three tellinid bivalves. J. Mar. Res. 70, 794-823 (2012).

24. Lopez-Urrutia, A., Martin, E. S., Harris, R. P. \& Irigoien, X. Scaling the metabolic balance of the oceans. Proc. Natl. Acad. Sci. U. S. A. 103, 8739-8744 (2006).

25. Kroeker, K. J. et al. Impacts of ocean acidification on marine organisms: Quantifying sensitivities and interaction with warming. Glob. Change Biol. 19, 1884-1896 (2013).

26. Moens, T. et al. Diatom feeding across trophic guilds in tidal flat nematodes, and the importance of diatom cell size. J. Sea Res. 92, 125-133 (2014).

27. Beman, J. M. et al. Global declines in oceanic nitrification rates as a consequence of ocean acidification. Proc. Natl. Acad. Sci. U. S. A. 108, 208-213 (2011).

28. Braeckman, U. et al. Empirical evidence reveals seasonally dependent reduction in nitrification in coastal sediments subjected to near future ocean acidification. PLoS One 9, e108153 (2014).

29. Thomsen, J., Casties, I., Pansch, C., Körtzinger, A. \& Melzner, F. Food availability outweighs ocean acidification effects in juvenile Mytilus edulis: Laboratory and field experiments. Glob. Change Biol. 19, 1017-1027 (2013).

30. Rossoll, D. et al. Ocean acidification-induced food quality deterioration constrains trophic transfer. PLoS One 7, e34737 (2012).

31. Mora, C. et al. Biotic and human vulnerability to projected changes in ocean biogeochemistry over the $21^{\text {st }}$ century. PLoS Biol. 11, e1001682 (2013). 
Correspondence and requests for materials should be addressed to C.V.C.

\section{Acknowledgements}

The research leading to results presented in this publication was carried out with infrastructure funded by EMBRC Belgium - FWO project GOH3817N. This work was co-funded by a MARES Joint Doctorate program Grant (2012-1720/001-001-EMJD) to E.Z.O. C.V.C. acknowledges the Research Foundation Flanders (FWO) for his postdoctoral research fellow grant (FWO-11.2.380.11.N.00).

Pressure sensor development was funded by grants from the US Office of Naval Research (N000140310352) and the US National Science Foundation (OCE 0928002) to S.A.W. and D.S.W. Additional funding for this project was obtained from the Special Research Fund (BOF) from Ghent University through GOA-projects 01GA1911W and 01G02617. The authors acknowledge Flanders Marine Institute (VLIZ) for the total alkalinity measurements.

\section{Author contributions}

C.V.C and E.Z.O share first authorship of this article. C.V.C and E.Z.O conceived and carried out the experiments. C.V.C., E.Z.O., M.B., E.A., and S.A.W. analysed the data. C.V.C., M.B., D.S.W., T.M., and S.A.W. contributed materials. C.V.C and E.Z.O co-wrote the manuscript. All authors proofread the manuscript, provided input and approved the manuscript.

\section{Data availability}

The data supporting the findings of this study are available at the Marine Data Archive (mda.vliz.be) via https://doi.org/10.14284/389 or from the corresponding author upon reasonable request. 


\section{Methods}

Experimental design behavior study. Adult individuals of Scrobicularia plana (shell length $29.61 \pm$ 3.25 SD mm per individual, $\mathrm{n}=51$ ) were collected in March 2017 at the Paulina tidal flat (Schelde estuary, The Netherlands $\left.\left(51^{\circ} 21^{\prime} 01.5^{\prime \prime} \mathrm{N} 3^{\circ} 43^{\prime} 51.4^{\prime \prime} \mathrm{E}\right)\right)$. Individuals were transported within 2 hours to the research facility and randomly allocated to microcosms $(n=4$ per treatment $)$ at a density of one individual per microcosm $(\varnothing=12 \mathrm{~cm}$, height $=20 \mathrm{~cm})$. Microcosms were prefilled with $15 \mathrm{~cm}$ of sediment from the sampling site which had been sieved over a 1-mm mesh size sieve (median grain size: $207.96 \pm 12.90 \mathrm{SD} \mu \mathrm{m}, \mathrm{n}=16$ ). Microcosms were incubated in four $200 \mathrm{~L}$ tanks with recirculating seawater $\left(650 \mathrm{~L} \cdot \mathrm{h}^{-1}, 10^{\circ} \mathrm{C}, \mathrm{pH}_{\mathrm{T}}\right.$ 8.00) for two weeks. Subsequently, the seawater temperature and $\mathrm{pH}$ were manipulated following a fully crossed design to simulate ocean warming and acidification relative to the natural conditions experienced by the collected organisms ${ }^{32}$; the temperature of the seawater was increased by $3{ }^{\circ} \mathrm{C}$ and the $\mathrm{pH}$ of the seawater was lowered by $\sim 0.35$ $\mathrm{pH}_{\mathrm{T}}$ below the ambient $\mathrm{pH}$ at the field site during the two months preceding the experiment (average January - February 2017 pH $_{\mathrm{T}}$ 7.80; Supplementary Fig. 2). Manipulations were done gradually over one week, and then maintained for 4 more weeks (Supplementary Table 4). The seawater pH of acidification treatments was manipulated and controlled via the bubbling of pure $\mathrm{CO}_{2}$ using an IKS Aquastar Industrial control panel coupled with compression-proof $\mathrm{pH}$ glass electrodes that were calibrated weekly with IKS GmbH NBS buffer solutions (pH 4.01 and 7.01). The seawater temperature was regulated (Teco Refrigeration technologies; Model: TK2000H) and recorded together with the $\mathrm{pH}_{\mathrm{NBS}}$ every 10 minutes. In order to maintain the salinity and remove the build-up of nutrients, $20 \%$ of the total volume was removed and refilled with fresh seawater on a weekly basis. All incubation tanks were subjected to a 12:12 h light : dark regime and individuals were fed twice a week with $0.5 \mathrm{~mL}$ of commercial Shellfish Diet 1800 (Reed Mariculture Inc.) diluted in $4 \mathrm{~L}$ of fresh seawater that was distributed evenly in each tank. $200 \mathrm{~mL}$ of seawater was collected from the incubation tanks and filtered through GF/F filter papers for the quantification of total alkalinity (TA) using a HydroFIA titrator. The carbonate chemistry was calculated from the obtained values for temperature, $\mathrm{pH}$, TA and salinity (WTW portable conductivity meter LF320) using CO2SYS software 
${ }^{33}$. At the end of the experiment, vertical profiles of porewater $\mathrm{pH}$ were determined in 3 microcosms of each treatment at 3-mm sampling intervals using a Unisense $\mathrm{pH}$ microsensor (tip size $500 \mu \mathrm{m}$ ). All $\mathrm{pH}_{\mathrm{NBS}}$ values were converted to total scale $\left(\mathrm{pH}_{\mathrm{T}}\right)$, following ${ }^{34}$ using the MATLAB program for $\mathrm{CO}_{2}$ calculations ${ }^{35}$.

Behavior recordings. We used pressure sensors (Honeywell type 26PC) to measure the hydraulic activity of $S$. plana ${ }^{36,37}$. The pressure sensor was built into a plastic pipe $(\varnothing=1.2 \mathrm{~cm}$, height $=11.5$ $\mathrm{cm}$ ) with an open top and a sealed bottom. The pressure port was positioned close to the outer wall of the plastic pipe and covered with a $64-\mu \mathrm{m}$ nylon mesh, whereas the reference port was positioned in a seawater plenum on the inside of the pipe. The hydraulic activities were recorded at a rate of $200 \mathrm{~Hz}$ (National Instruments with SignalExpress 2014 software) during light conditions for $\sim 27 \mathrm{~h}$ in week 2 (i.e. prior to $\mathrm{pH}$ and temperature manipulation) and week 6 (i.e. third week of stable $\mathrm{pH}$ and temperature settings). Pressure data was downscaled to $1 \mathrm{~Hz}$ and smoothed using a running median per hour to reduce noise. Prior to the experiment, a calibration was conducted to determine the relationship between sensor output $(\mathrm{mV})$ and hydraulic head. Porewater hydraulic signatures were linked to clam behaviors using synchronized 10-second interval time-lapsed images and pressure records from a pilot experiment: burrowing, suspension feeding with the inhalant siphon stretching out in the water column or at the sediment water interface, and deposit feeding with the inhalant siphon grazing at the sediment surface and often followed by valve claps to expel pseudofaeces at the sediment surface (Fig. 1d).

Statistical methods behavior study. Burrowing was not analyzed because it occurred only once when individuals were placed on the sediments and no longer after manipulation of seawater $\mathrm{pH}$ and temperature. One-way analysis of variance revealed that there were no significant differences $(p$ > 0.05 ) in feeding behaviors (total time and frequency of events) between the four groups of individuals prior to manipulation when suspension feeding was the predominant feeding mode $(>74.5 \%$ of feeding time in all groups)(Supplementary Fig. 1). Consequently, we compared differences in feeding behavior in week 6 between the four treatments using two-way crossed analysis of variance.

Suspension feeding frequency data was $\log _{10}$ transformed to improve normality (Q-Q plots), and 
homogeneity of variances was checked using Levene's test. All analyses were performed using Rsoftware version 3.5.1 ${ }^{38}$.

Experimental design sediment community study. In September 2017, when all dominant macrofauna (i.e. sediment fauna $>0.5 \mathrm{~mm}$ in size) species have recruited at the field site ${ }^{39}$, sediment communities and adult individuals of Scrobicularia plana (shell length $31.16 \pm 2.48$ SD mm per individual, $\mathrm{n}=50$ ) were collected from the same location as where clams for the behavioral experiment were collected. Twenty communities were sampled till a depth of $12 \mathrm{~cm}$ from homogenous patches of sediment $(30 \mathrm{~cm} \times 20 \mathrm{~cm}$ ) without star-shaped deposit feeding tracks of S. plana. Complete sediment "blocks" (median grain size: $232.03 \pm 3.93 \mathrm{SD} \mu \mathrm{m}, \mathrm{n}=20$ ) were transferred without disturbance to trays (length : $30 \mathrm{~cm} \times$ width: $20 \mathrm{~cm} \times$ depth: $17 \mathrm{~cm}$ ) and transported to the laboratory within 2 hours after collection in the field. Prior to manipulation of S. plana presence and of seawater temperature and $\mathrm{pH}$, sediment communities were left to acclimatize separately for one week in ten incubation tanks (2 trays per tank) filled with recirculating seawater at ambient conditions $\left(17^{\circ} \mathrm{C}, \mathrm{pH}_{\mathrm{T}}\right.$ 8.03). The two communities were separated by a net (height $=35 \mathrm{~cm}$, mesh size $=1 \mathrm{~mm}$ ) to prevent migration of macrofauna between trays. S. plana individuals were acclimatized in a separate tank and randomly allocated at ambient density ( 5 clams per tray) to one tray per incubation tank after one week. After two weeks of acclimation, combined warming and acidification was simulated by gradually heating and lowering the $\mathrm{pH}$ of the seawater in 5 tanks during one week in a similar way as described for the behavior experiment. The simulated climate change conditions $\left(+3^{\circ} \mathrm{C}\right.$ and $\sim 0.35 \mathrm{pH}$ units below the ambient $\mathrm{pH}$ at the field site during the two months preceding the experiment (average July - August $2017 \mathrm{pH}_{\mathrm{T}}$ 7.99; Supplementary Fig. 2) were maintained for 4 more weeks (Supplementary Table 4). A TRIS buffer with a salinity of 35 was used to convert the $\mathrm{pH}_{\mathrm{NBS}}$ values to total scale $\left(\mathrm{pH}_{\mathrm{T}}\right)^{40}$. Size of the tanks, flow, feeding, and maintenance regime were identical as described for the behavior experiment, and so were the sampling and analysis of the seawater carbonate chemistry.

Sampling porewater nutrients, benthic microalgae and fauna. At the termination of the experiment, sediment porewater was collected from the upper $5 \mathrm{~cm}$ using a rhizon soil moisture 
sampler (mean pore size $0.15 \mu \mathrm{m})\left(\mathrm{n}=2\right.$ per tray) and stored at $-20{ }^{\circ} \mathrm{C}$ until subsequent dissolved inorganic nutrient analysis using automated colorimetric analysis (CFA, SKALAR). Furthermore, sediment chlorophyll a (a proxy for benthic microalgal biomass) and its degradation products (phaeophorbide and phaeophytin) were quantified using HPLC analysis (Agilent) ${ }^{41}$ from 1-cm deep sediment samples (surface area $10 \mathrm{~cm}^{2}$; one per tray) that were stored frozen $\left(-80^{\circ} \mathrm{C}\right)$ prior to extraction with acetone at $4{ }^{\circ} \mathrm{C}$ in the dark for 24 hours. To assess the freshness of organic matter derived from primary production by benthic microalgae, as a proxy for herbivore food quality, we applied the ratio of chlorophyll a : phaeopigments ${ }^{42}$. Another three 1-cm deep sediment samples (surface area $10 \mathrm{~cm}^{2}$ ) were collected per tray and stored in $8 \%$ buffered formaldehyde until quantification of nematodes. The remaining sediment was sieved through a $0.5 \mathrm{~mm}$ sieve and preserved in $8 \%$ buffered formaldehyde until macrofauna species identification and biomass quantification (blotted wet weight). All S. plana were alive at the end of the experiment.

Statistical methods sediment community study. Structural equation modeling (SEM) was conducted using the Lavaan package in $\mathrm{R}^{43}$ to evaluate the relative strengths of potential direct and indirect effects of S. plana on the sediment community (pore water nutrients, primary producers and the dominant macrofaunal species $H$. filiformis, $P$. ulvae, and $H$. diversicolor). A maximum likelihood $\chi^{2}$ with robust Huber-White standard errors and a Yuan-Bentler statistic were used to test whether the generated covariance matrix differed significantly from the conceptual interaction network supported by empirical evidence where (1) S. plana affected H. filiformis, P. ulvae, and H. diversicolor directly via bioturbation interference effects ${ }^{17}$, (2) all macrofauna affected porewater nutrients via excretion and change in biogeochemistry ${ }^{44}$, (3) all macrofauna species affected benthic microalgae via grazing or change in nutrient limitation ${ }^{14,45-47}$, (4) H. diversicolor affected S. plana, H. filiformis, and P. ulvae, via predation and bioturbation interference effects ${ }^{48,49}$, and (5) porewater nutrients affected benthic microalgae ${ }^{47}$. Given the observed behavioral change of S. plana in response to warming and acidification which might change interactions between porewater nutrients, benthic microalgae and faunal populations, we developed SEMs based on the data derived from either ambient temperature and $\mathrm{pH}$ conditions or combined warming and acidification. We calculated a best-fit model for both 
conditions by removing direct non-significant links $(\mathrm{p}>0.05)$ between ecosystem components, increasing the comparative fit index and decreasing Akaike's information criterion while maintaining non-significant tests for goodness of fit $\left(\chi^{2}\right)$ and the standardized root mean square error of approximation ${ }^{50,51}$. Finally, we compared the best-fit model for the ambient temperature and $\mathrm{pH}$ data to the combined warming and acidification data, and vice versa, to ensure that both networks were different (Supplementary Table 3). For porewater nutrients, we included $\mathrm{NO}_{3}{ }^{-}$because this nitrogen species is preferentially utilized by benthic microalgae in temperate estuaries when ammonium concentrations are high ${ }^{52,53}$ and $\mathrm{NO}_{3}{ }^{-}$was shown to correlate to the microalgal community structure at the study site ${ }^{47}$. Furthermore, oxygenation of the sediment by species such as $H$. diversicolor and tellinid bivalves is known to affect porewater $\mathrm{NO}_{3}{ }^{-}$concentrations ${ }^{21,44}$. For microalgae, we used the proportion of living : dead microalgae since microalgal biomass did not return significant models (data not shown), possibly because of the fast mineralization of microalgal carbon in the tray. As ecosystem interactions mediated by sediment fauna are often size-dependent ${ }^{54}$, we used the total biomass instead of the density, except for $H$. filiformis where mostly incomplete individuals were retrieved after sieving.

Linear mixed effects models were used to test the effects of climate condition (unmanipulated versus combined warming and acidification), S. plana (absent versus present), and their interaction, on porewater nutrients, benthic microalgal biomass, and the proportion of living : dead microalgae, using the Kenward-Roger method to estimate degrees of freedom. All response variables were $\log _{10}$ transformed prior to analysis in order to improve normality, and Q-Q plots were used to check the model assumptions. Effects on the density of dominant macrofauna species and surface-dwelling nematodes were analyzed with generalized linear mixed models using Poisson distribution of data and $\log$ likelihood ratio tests to calculate the $\chi^{2}$ statistic and associated $p$-values for each effect. We took into account the non-independence of the two trays per tank by allowing random intercepts for tank identity in all tests. For porewater nutrients and nematode density we used the average data from the multiple samples that were collected per tray. All analyses were performed using packages lme $4{ }^{55}$, lmerTest and pbkrTest ${ }^{56}$ in the R software version 3.5.1 ${ }^{38}$. As one adult $S$. plana was found in one of 
the replicates from the combined warming and acidification treatment without $S$. plana, this particular replicate was removed from the SEM and mixed effect models.

32. Vargas, C. A. et al. Species-specific responses to ocean acidification should account for local adaptation and adaptive plasticity. Nat. Ecol. Evol. 1, 1-7 (2017).

33. Pierrot, D., Lewis, E. \& Wallace, D. W. R. MS Excel program developed for $\mathrm{CO}_{2}$ system calculations. ORNL/CDIAC-105a. Carbon Dioxide Inf. Anal. Center, Oak Ridge Natl. Lab. US Dep. Energy, Oak Ridge, Tennessee (2006).

34. Zeebe, R. \& Wolf-Gladrow, D. $\mathrm{CO}_{2}$ in seawater-equilibrium, kinetics, isotopes. Elsevier Oceanogr. Ser. 65, (Elsevier, Amsterdam, 2001).

35. Van Heuven, S., Pierrot, D., Rae, J. W. B., Lewis, E. \& Wallace, D. W. R. MATLAB program developed for $\mathrm{CO}_{2}$ system calculations. Oak Ridge, Tennessee Carbon Dioxide Inf. Anal. Center, Oak Ridge Natl. Lab. US Dep. Energy. pp. ORNL/CDIAC-105b (2011).

36. Wethey, D. S. \& Woodin, S. A. Infaunal hydraulics generate porewater pressure signals. Biol. Bull. 209, 139-145 (2005).

37. Woodin, S. A., Wethey, D. S. \& Volkenborn, N. Infaunal hydraulic ecosystem engineers: cast of characters and impacts. Integr. Comp. Biol. 50, 176-87 (2010).

38. R Core Team. R: A language and environment for statistical computing. R Foundation for Statistical Computing, Vienna, Austria (2018).

39. Van Colen, C. et al. Macrobenthic recovery from hypoxia in an estuarine tidal mudflat. Mar. Ecol. Prog. Ser. 372, 31-42 (2008).

40. Dickson, A. G. Part 1 : Seawater carbonate chemistry. The carbon dioxide system in seawater: equilibrium chemistry and measurements. Guide to best practices for ocean acidification research and data reporting (2010).

41. Wright, S. W. \& Jeffrey, S. W. High-resolution HPLC system for chlorophylls and carotenoids of marine phytoplankton. (Unesco Pub., 1997).

42. Campanyà-llovet, N., Snelgrove, P. V. R. \& Parrish, C. C. Rethinking the importance of food quality in marine benthic food webs. Prog. Oceanogr. 156, 240-251 (2017). 
43. Rosseel, Y. lavaan: an R package for structural equation modeling and more Version 0.3-1 (BETA). (2011).

44. Michaud, E., Desrosiers, G., Mermillod-blondin, F., Sundby, B. \& Stora, G. The functional group approach to bioturbation: II. The effects of the Macoma balthica community on fluxes of nutrients and dissolved organic carbon across the sediment - water interface. J. Exp. Mar. Bio. Ecol. 337, 178-189 (2006).

45. Herman, P. M. J., Middelburg, J. J., Widdows, J., Lucas, C. H. \& Heip, C. H. R. Stable isotopes as trophic tracers: combining field sampling and manipulative labelling of food resources for macrobenthos. Mar. Ecol. Prog. Ser. 204, 79-92 (2000).

46. Weerman, E. J. et al. Changes in diatom patch-size distribution and degradation in a spatially self-organized intertidal mudflat ecosystem. Ecol. Soc. Am. 93, 608-618 (2012).

47. Sahan, E. et al. Community structure and seasonal dynamics of diatom biofilms and associated grazers in intertidal mudflats. Aquat. Microb. Ecol. 47, 253-266 (2007).

48. Hiddink, J. G., Ter Hofstede, R. \& Wolff, W. J. Predation of intertidal infauna on juveniles of the bivalve Macoma balthica. J. Sea Res. 47, 141-159 (2002).

49. Scaps, P. A review of the biology, ecology and potential use of the common ragworm Hediste diversicolor (O. F. Müller) (Annelida: Polychaeta). Hydrobiologia 470, 203-218 (2002).

50. Kline, R. B. Principles and practice of structural equation modeling. (Guilford publications, 2015).

51. Thrush, S. F. et al. Experimenting with ecosystem interaction networks in search of threshold potentials in real-world marine ecosystems. Ecology 95, 1451-1457 (2014).

52. Lomas, M. W. \& Glibert, P. M. Temperature regulation of nitrate uptake : A novel hypothesis about nitrate uptake and reduction in cool-water diatoms. Limnol. Oceanogr. 44, 556-572 (1999).

53. Glibert, P. M. et al. Pluses and minuses of ammonium and nitrate uptake and assimilation by phytoplankton and implications for productivity and community composition, with emphasis on nitrogen-enriched conditions. Limnol. Oceanogr. 61, 165-197 (2016). 
54. Norkko, A., Villna, A., Norkko, J., Valanko, S. \& Pilditch, C. Size matters: Implications of the loss of large individuals for ecosystem function. Sci. Rep. 3, 1-7 (2013).

55. Bates, D., Mächler, M., Bolker, B. \& Walker, S. Fitting Linear Mixed-Effects Models Using lme4. J. Stat. Softw. 67, 51 (2015).

56. Kuznetsova, A., Brockhoff, P. B. \& Christensen, R. H. B. Tests in Linear Mixed Effects Models Version. Packag. 'ImerTest' R package, 2-0 (2015) 


\section{Figure captions}

Fig. 1. Effects of warming and acidification on clam feeding behavior as revealed from hydraulic porewater signatures. a, Suspension feeding and deposit feeding frequency. $\mathbf{b}$, The total duration of suspension feeding and deposit feeding (colour key as in a). Data are means \pm SE. Hydraulic waveforms linked to suspension and deposit feeding are presented in $\mathbf{c}$ and $\mathbf{d}$, respectively. The asterisk (*) in $\mathbf{d}$ denotes negative pressurization associated with pseudofaeces production following the deposit feeding event. Example signatures presented in $\mathbf{c}$ and $\mathbf{d}$ were collected from the same individual on the same day.

Fig. 2. Effects of combined warming and acidification and S. plana on sediment abiotic properties. Effect on microalgal biomass (a), porewater $\mathrm{NO}_{2}^{-}(\mathbf{b})$, porewater $\mathrm{NO}_{3}^{-}(\mathbf{c})$, porewater $\mathrm{Si}$ (d), porewater $\mathrm{PO}_{4}{ }^{3-}(\mathbf{e})$, and the proportion living : dead microalgae (f). Data are means $\pm \mathrm{SE}$.

Fig. 3. Effects of combined warming and acidification and S. plana on sediment fauna. Effect on the density of $H$. filiformis (a), P. ulvae (b), H. diversicolor (c), and nematodes in the upper first $\mathrm{cm}$ (d). Data are means \pm SE.

Fig. 4. Changes in ecosystem interaction networks associated with combined warming and acidification. Significant paths $(\mathrm{p}<0.05)$ are shown as solid arrows, non-significant paths that had to be retained for model stability as dashed arrows. Widths of arrows are proportional to the standardized path coefficient, and only the paths shown in the diagram were included in the best model. Blue and red arrows indicate respectively positive and negative linkages between ecosystem components. Model statistics are presented in Supplementary Table 3. 
Figure 1
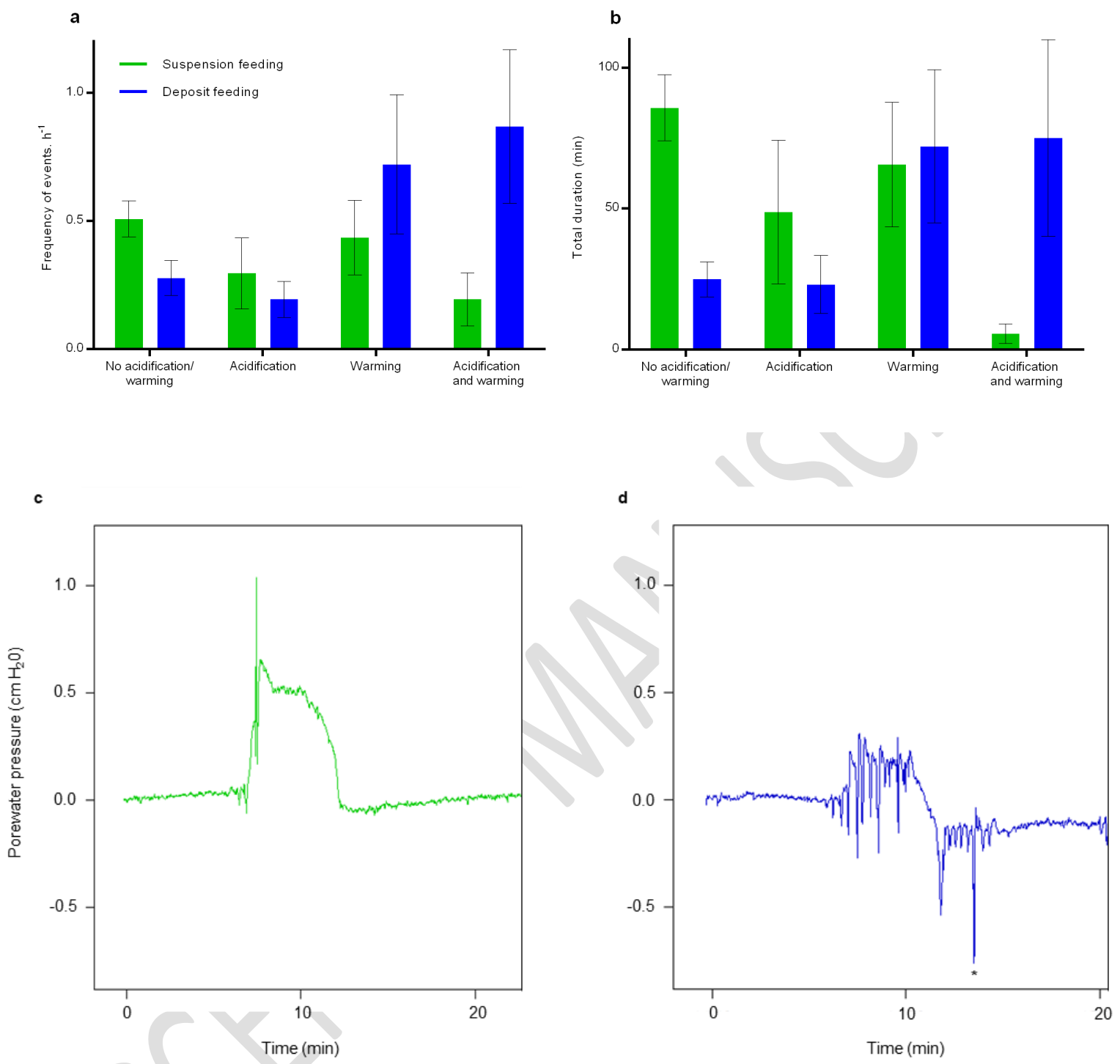
Figure 2

a
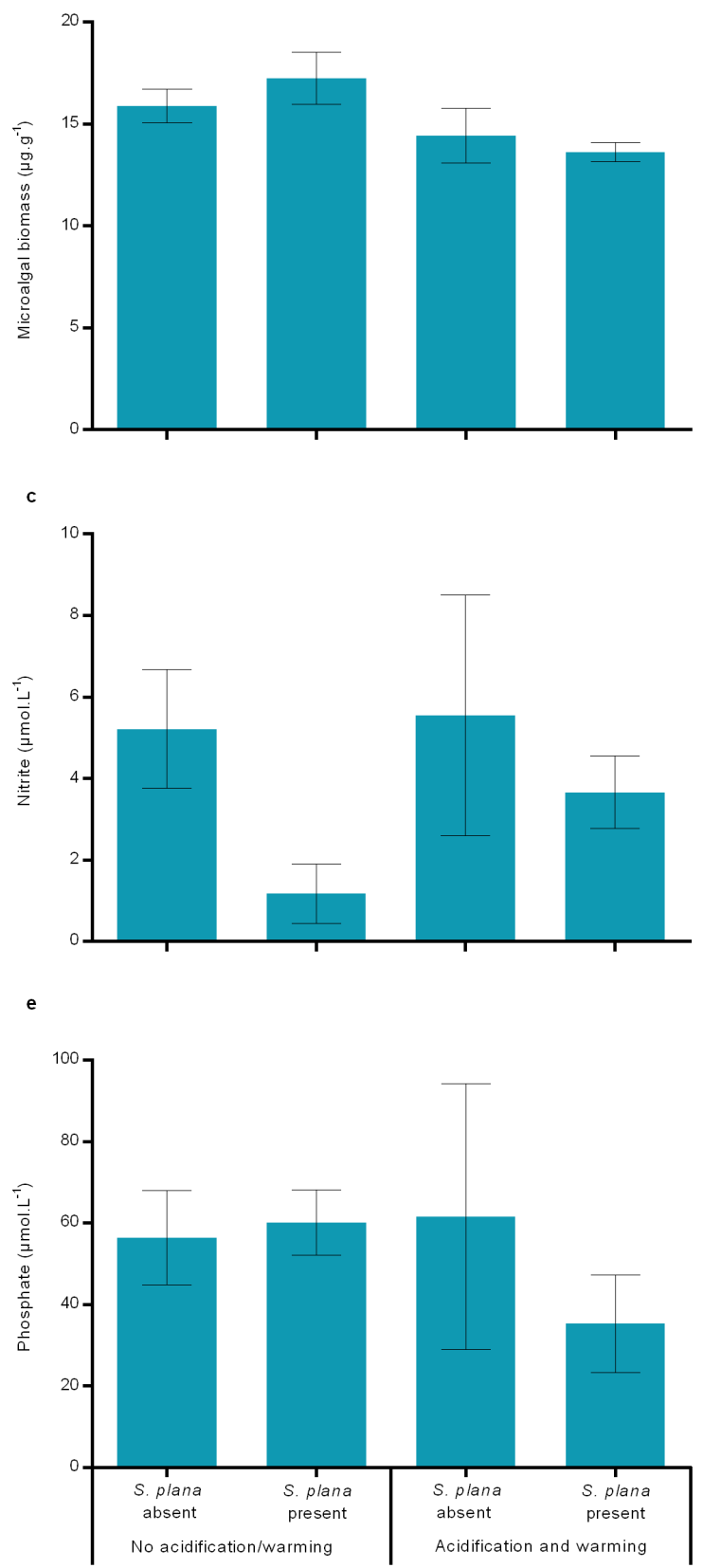

b
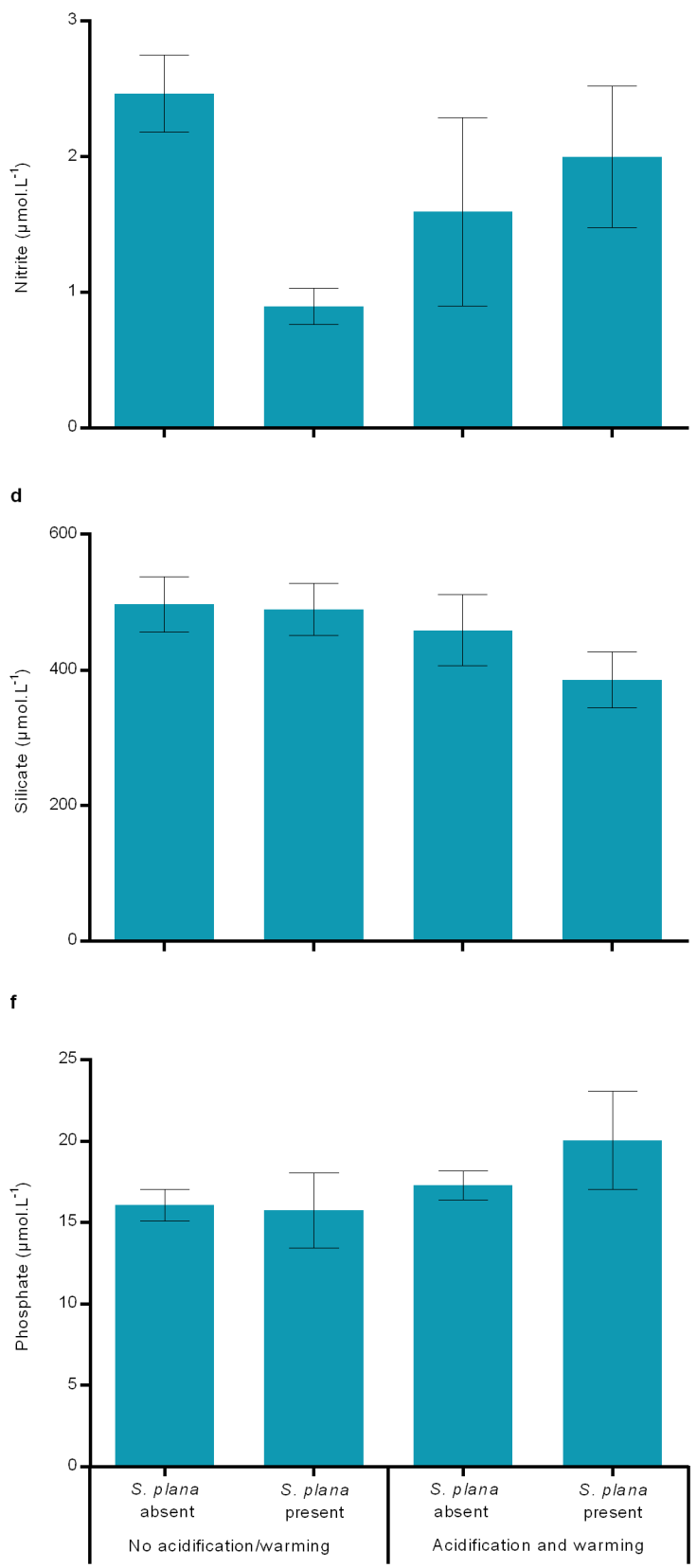
Figure 3

a
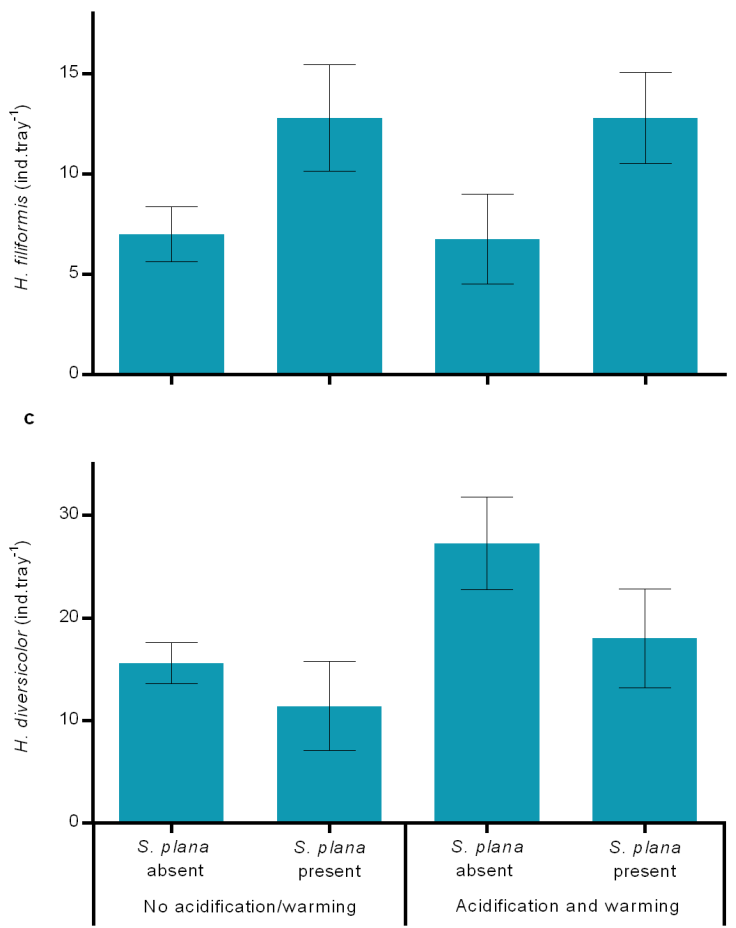
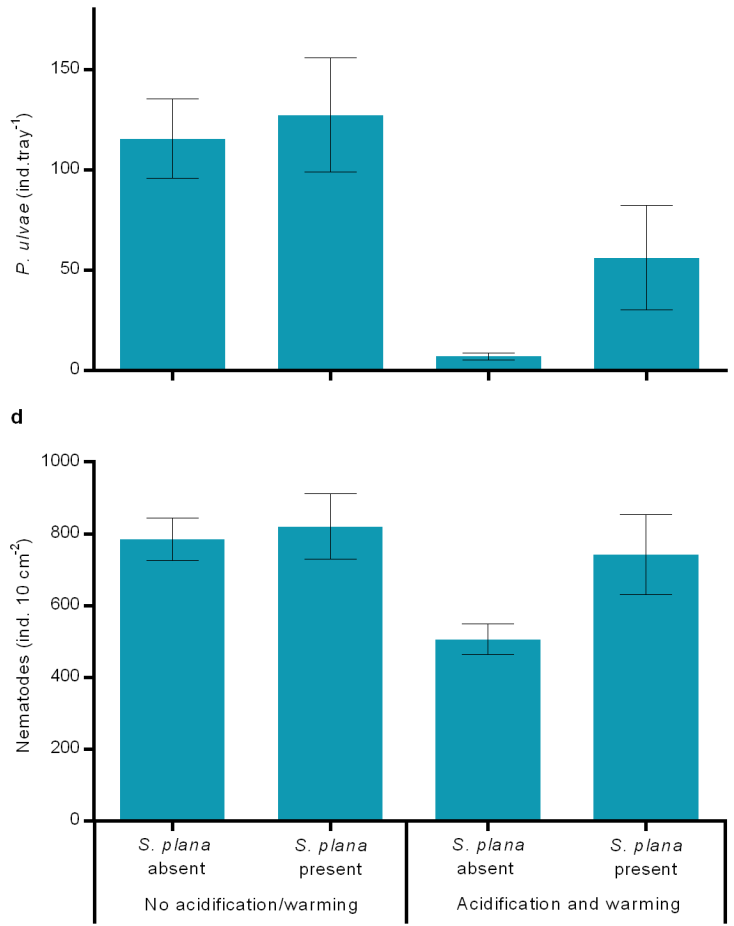
Figure 4
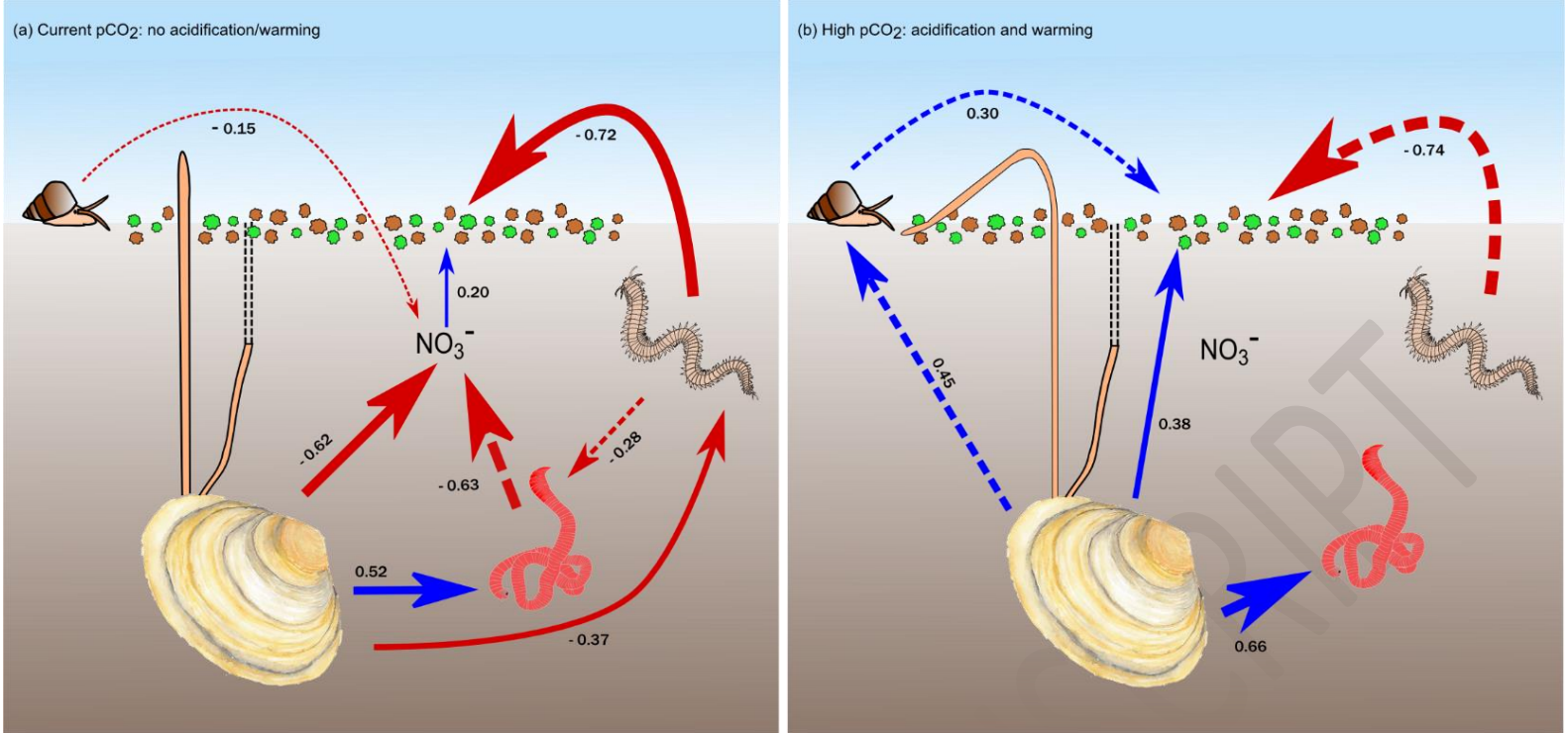


\section{Extended Data Figure 1}

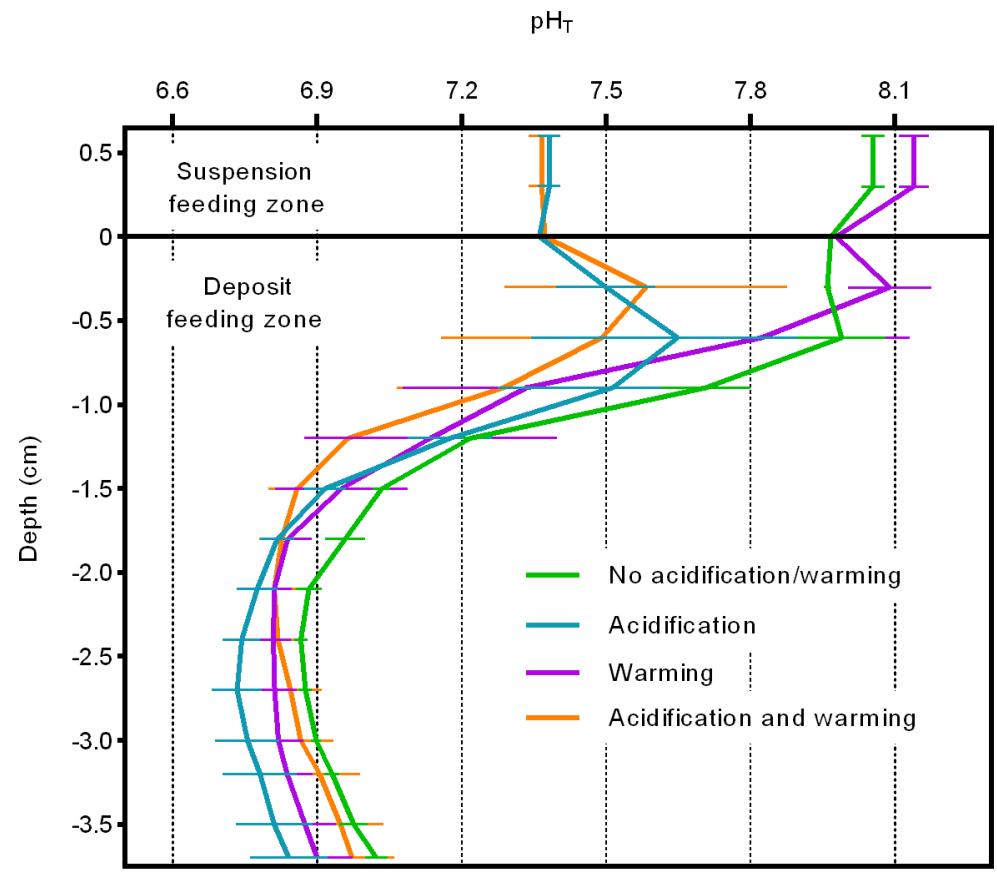

